\title{
Utilization of Vegetable Wastes for Bioenergy Generation
}

\author{
Anshu Singh $\cdot$ Arindam Kuila $\cdot$ Sunita Adak $\cdot$ \\ Moumita Bishai · Rintu Banerjee
}

Received: 21 February 2012/ Accepted: 19 July 2012/Published online: 14 August 2012

(C) NAAS (National Academy of Agricultural Sciences) 2012

\begin{abstract}
Vegetable wastes occur throughout the supply chain and vary widely depending on its processing. Globally, more than $30 \%$ of the loss occurs at the retail and consumer levels, of which the post-harvest and processing level wastages account for the major share. The wastes so generated pose an environmental threat and call for the development of a pollution-free model. Studies on the characterization of unutilized, rotten, and discarded fractions of the vegetable wastes indicate their potential candidature for reprocessing. Generation of renewable energy by bioconversion of vegetable wastes is gaining importance as it has proved to be a proficient means of utilizing the perishable vegetable residues. Researchers and industries are now fully engaged in a number of projects involving the technology of "waste to fuel" with a view to overcome the disposal problems. The present article deals with the studies conducted on vegetable wastes for production of various types of biofuel.
\end{abstract}

Keywords Vegetable waste $\cdot$ Biofuel $\cdot$ Bioethanol $\cdot$ Biogas $\cdot$ Biomethane $\cdot$ Biohydrogen $\cdot$ Biodiesel

\section{Introduction}

Bioenergy is a promising, inexhaustible, sustainable source to combat the rising environmental, economic, and technological issues related to depleting fossil fuels. The most important aspect for sustainable production and supply of bioenergy is the availability of feedstock. Among various substrates, production from wastes has received a special acceptance for maintaining environmental integrity. Wastes are generated in many forms and at various stages, ranging from domestic to industrial levels, and their improper disposal has detrimental effects on the environment as well as human life.

The human population across the globe is increasingly getting oriented toward healthy and processed food

\footnotetext{
A. Singh $\cdot$ A. Kuila $\cdot$ S. Adak $\cdot$ M. Bishai $\cdot$ R. Banerjee $(\square)$ Microbial Biotechnology and Downstream Processing Laboratory, Agricultural and Food Engineering Department, Indian Institute of Technology, Kharagpur 721302, West Bengal, India

e-mail: rintuin@gmail.com; rb@iitkgp.ac.in
}

products. It has been observed that of the enormous supply of food for human consumption, about one-third gets wasted globally [26]. India, with rich agricultural resources, accounts for 50 MT of vegetable waste, which is about $30 \%$ of its total production [96]. Hence, utilization of these wastes generated at different levels of delivery starting from the agricultural farm, post-harvest handling, storage, processing, and from distribution to consumption would be economically highly beneficial. Such wastes can either be used directly as an untreated material for microbial growth or be used by appropriate treatment with enzymes for bioenergy production. The products generated from perishable wastes can be in liquid or gaseous forms of biofuels. Since the process is rather specific and varies for conversion into different types of biofuels, it is necessary that the quality, quantity, and characteristics of the feedstock are known or determined beforehand. Based on initial screening and biochemical characterization of the wastes, treatment processes can be designed to recover energy from waste nutrients. Utilization of microbes or enzymes for digestion of discarded vegetable biomass into a desired form of fuel is presently one of the most accepted waste 
Table 1 Physical characteristics of different types of vegetable wastes on a dry weight basis

\begin{tabular}{lllll}
\hline Waste & Moisture (\%) & Ash $(\%)$ & Total solid (\%) & References \\
\hline Potato (leachate/solid waste) & $85-87$ & $6-12$ & $1.7-19$ & {$[1,2,67,68,101]$} \\
Tomato (solid waste) & $85-90$ & $3.1-5.3$ & $7-22.4$ & {$[8,34,76,92]$} \\
Onion (onion tops peelings and whole bulbs) & $82-92.6$ & $4.7 \pm 0.1$ & $91 \pm 0.25$ & {$[8,9]$} \\
Pea (peel, shell, and solid waste) & $84-88.5$ & $4.80-15.5$ & $11.11-39$ & {$[8,17,18,25,97]$} \\
Sugar beet (pulp, silage, and leaves) & $85 \pm 0.1$ & $3.81-8.85$ & $7-11$ & {$[33,61,63]$} \\
\hline
\end{tabular}

Table 2 Chemical characteristics of different types of vegetable wastes

\begin{tabular}{lccccc}
\hline Waste & Starch $(\%)$ & Cellulose $(\%)$ & Hemicellulose $(\%)$ & Protein $(\%)$ & References \\
\hline Potato (Peel, mesh) & $30-40$ & $17-25$ & $10-15$ & $3-5$ & {$[45,53,59]$} \\
Tomato & $10-18$ & $30-32$ & $5-18$ & $17-22$ & {$[3,41,48,75]$} \\
Carrot & $1-2$ & $13-52$ & $12-19$ & $5-8$ & {$[6,19,52,64,80]$} \\
\hline
\end{tabular}

management strategies. The present article focuses on the strategic application of bioconversion processes on vegetable wastes used to develop environmentally friendly and low-cost operating systems for production of biofuel.

\section{Vegetable Wastes}

Vegetable waste is a biodegradable material generated in large quantities, much of which is dumped on land to rot in the open, which not only emits a foul odor, but also creates a big nuisance by attracting birds, rats, and pigs-vectors of various diseases. Apart from post-harvest losses due to lack of storage capacity, processing and packaging of vegetables according to customers' specifications also plays a major role in waste generation. Vegetable wastes include the rotten, peels, shells, and scraped portions of vegetables or slurries.

These wastes can be treated for biofuel production through fermentation under controlled conditions or else used for composting. The natural decomposition of wastes by microbes generates products with high humus content. Research activities have confirmed that this carbohydraterich biomass can be a potent substrate for renewable energy generation.

\section{Characterization of Vegetable Wastes}

Vegetable and fruit wastes are a special group of biomass that needs to be characterized to understand its nature for application as raw material and to propose the best methodology for its proper utilization. Waste composition also influences the overall yield and kinetics of the biologic reaction during digestion. Characterization of waste can be done physically, chemically, or biologically. Physical characterization of solid wastes include estimation of weight, volume, moisture, ash, total solid, volatile solid (VS), color, odor, temperature, etc., while dissolved and suspended solids are estimated for liquid wastes. Turbidity is another important parameter for liquid wastes, which needs to be considered. Chemical studies include the measurement of cellulose, hemicellulose, starch, reducing sugars, protein, total organic carbon, phosphorus, nitrogen, BOD, COD, pH, halogens, toxic metals, etc. Besides these biochemical parameters, carbon, phosphorous, potassium, sulfur, calcium, magnesium, etc. can also be tested. All these chemical and biochemical parameters provide an insight on the applicability of waste for employment in specific energy production. Biologic characterization indicates the presence of pathogens and organisms which are indicators of pollution. A common feature of various forms of food wastes includes high COD, richness in protein, carbohydrate, and lipid biomolecules with noticeable $\mathrm{pH}$ variation. Joshi et al. [38] reported that wastes from vegetables industries including carrot, peas, and tomatoes have a high BOD and are a rich source of several nutrients like vitamins, minerals, fibers, etc. So, a detailed study of waste characteristics is essential for deciding its application and determination of economic feasibility of the process. Some of the physical and chemical characteristics of vegetable wastes have been given in Tables 1 and 2, respectively.

\section{Waste to Bioenergy}

Conversion of wastes to energy helps in resource conservation and environmental safety on a sustainable basis. Specific gaseous and liquid biofuels are dealt with in detail in the following sections. 
Biomethane

Biomethane, obtained during anaerobic digestion by the microbial community, is a cheap form of renewable energy that is environmentally friendly. Normally, biogas is composed of 45-70\% methane, 30-45\% carbon dioxide, $0.5-1.0 \%$ hydrogen sulfide, $1-5 \%$ water vapor, and a small amount of other gases (hydrogen, ammonia, nitrogen, etc.) [94]. Composition of a particular biofuel varies with the source and concoction of biodegradable biomass [101]. The potential of biogenic waste for gas production depends highly on its nature and biochemical composition [77]. Use of vegetable waste for biogas production not only solves the problem of residual disposal and indoor pollution, but also reduces dependency on fuel wood.

Biomethane production is a three-step process involving hydrolysis, acidogenesis, and methanogenesis which is accomplished by a series of microbial interactions. Since the three stages of anaerobic digestion are controlled by bacteria, the product form varies with the type of bacterial population. Single stage digestion of vegetable waste is preferred owing to its lower investment cost and simpler design. However, a major problem related with the single phase digestion is the high loading rate that affects the growth and activity of methanogens. During anaerobic digestion, acetate, carbon dioxide, and hydrogen are produced as a result of the activities of acidogenic microbes. Hydrogen and acetate are assimilated by the methanogens and reduced to methane and water. At high loading rates, the metabolic activity of acidogenic microbes increases resulting in increased hydrogen accumulation, while methanogenic organisms are unable to increase the activity, and this disparity leads to the termination of methane production. High biodegradable organic content of vegetable waste causes rapid acidification and large volatile fatty acids production which inhibits the activity of methanogenic bacteria.

Though methane production is an age-old process, it still faces a major challenge in terms of enhancing the productivity and yield of the gas. For biomethane gas utilization, raw gas has to meet the quality characteristics of natural gas. High $\mathrm{CH}_{4}$ content in the biogas is the prime aim which can be achieved by removing most of the $\mathrm{CO}_{2}$ and hydrogen sulfide from the biogas. The amine scrubbing process is the technology mainly used for the treatment of biogas. Initial steps involve the removal of water and hydrogen sulfide. Desulfurization takes place with the help of an activated carbon filter.

Another important challenge associated with digestion is the loss of biomass in systems with a high hydraulic loading rate. A solution to this problem was found by designing reactors capable of high loading rates and small hydraulic retention times (HRT). During the single stage digestion process, digested slurries lack homogeneity in particle size resulting in the formation of layers of distinct densities, or phases, in the reactor. In general, it damages the propellers and hampers proper mixing, and thus the periodic extraction of the layers formed inside the reactor is essential. Normally, in the batch system, organic wastes are fed once in the reactor where they undergo sequential decomposition. The batch digesters have not yet been successful to meet the substantial market share due to high retention time [12]. The semi-continuous or continuous mode of anaerobic digestion of vegetable wastes is one of the most popular and significant methods [98, 104]. Continuous stirred tank reactors (CSTR) are more versatile bioreactors available for single phase digestion of vegetable wastes $[46,85]$. Uniform mixing of the biomass using a mechanical agitator or recycling of biogas results in the equalization of the hydraulic retention time to the solid retention time, thereby overall enhancing the biogas yield. Vegetable wastes were explored by Verrier et al. [97] in a 161 CSTR, resulting in VS removal and methane yield of $83 \%$ and $0.37 \mathrm{lg}^{-1} \mathrm{VS}$ fed, respectively. CSTR was also studied for digestion of vegetable residues by Lane et al. [49]. Digestion of asparagus and sugar beet pulp waste resulted in a methane yield of 0.230 and $0.263 \mathrm{lg}^{-1} \mathrm{VS}$ fed, respectively, and VS reduction up to 89.7 and $95.2 \%$, respectively. Using CSTR, Sarada and Joseph [78] evaluated tomato processing waste (peel, seed, and skin) and obtained the maximum yield of biogas $\left(0.42 \mathrm{lg}^{-1} \mathrm{VS}\right.$ fed) on the 24th day at $35{ }^{\circ} \mathrm{C}$ with a loading rate of $4.5 \mathrm{~kg} \mathrm{TS} \mathrm{m}^{-3}$.

Sequencing batch reactors are gaining more importance for anaerobic digestion than single stage digestion in terms of better solid retention and the absence of settling [95]. The use of two stage bioreactors for anaerobic treatment is of great significance because of its process flexibility in terms of HRT, organic loading rate due to sequential arrangement of separate bioreactors for acidogenesis and methanogenesis resulting in elimination of separate clarifiers [89]. The process includes the repetition of five separate steps: feeding, reacting, settling, drawing, and idle. The anaerobic sequential batch reactor performance for vegetable waste was found to be good. Bouallagui et al. [11] used ASBR as the methanogenic bioreactor in two phase digestion (of fruit and vegetable wastes) which resulted in significant biogas productivity and better effluent quality with a $96 \%$ reduced chemical oxygen demand. Two stage anaerobic digestion was used by Raynal et al. [74] for vegetable waste (potato peeling wastes, salad leaves, and cannery waste of green peas and carrots mixture) using multiple liquefaction reactors and a central methane reactor. Rajeshwari et al. [73] explored USAB digester for the sequential two stage digestion of vegetable wastes. Initial hydrolysis and acidification was 
performed in a bed reactor which resulted in leachate with COD $25,298 \mathrm{mg} \mathrm{l}^{-1}$ in $40 \mathrm{~h}$ which was fed to upflow anaerobic sludge blanket (UASB) for methane production. The anaerobic baffled reactor is another novel reactor used for biogas production from fruit and vegetable waste by Bouallagui et al. [10].

Improving the efficiency with the surplus supply of nutrients by the co-substrates and reducing the negative effect of toxic compounds on the digestion process with dilution are other aspects of enriching methane production. Lack of nitrogen and phosphorus in vegetable wastes make the co-digestion practice a reasonable means to balance the nutrients by adding other feedstock with high nitrogen or phosphorus [29]. Molinuevo-Salces et al. [62] used CSTR bioreactor for studying the effect of addition of vegetable processing waste $(50 \% \mathrm{dw} / \mathrm{dw})$ as co-substrate in the anaerobic digestion of swine manure. The results showed a threefold increase in methane yield at HRT of 23 days. Codigestion of tomato wastes with cattle dung performed by Saev et al. [76] in cylindrical-shaped anaerobic reactor in the ratio of 80:20 for cattle dung to tomato waste resulted in increased biogas yield from 0.33 to $0.700 \mathrm{dm}^{3} \mathrm{~d}^{-1}$. Two stage digestion of mixture of activated sludge and fruit/ vegetable wastes resulted in a methane content of $68 \%$ [21]. ASBR were utilized for the anaerobic co-digestion of abattoir wastewater and fruit/vegetable wastes at HRT of 10 and 20 days [13].

Anaerobic treatment of vegetable waste, rich in organic content, is advantageous as it not only results in the high yield of methane with varying organic loading, but also provides the digested slurry that can be used as soil conditioner/biomanure.

\section{Biodiesel}

Biodiesel comprises alkyl esters of high fatty acids and low aliphatic alcohols. A Biomass with high lipid content is most suitable for biodiesel production. Oil rich wastes of vegetable origin like fresh or waste vegetable oils, animal fats, and oilseed plants fall under this category. Fatty acid composition of the triglycerides present in the feedstock determines its usefulness as the calorific value depends on it. Unsaturation lowers the energy content, whereas saturation increases the calorific value. Other physical and chemical parameters controlling the efficiency of the feedstocks are the presence of moisture, impurities, and unsaponifiables [40]. The choice of feedstock also determines the cost of biodiesel which sometimes accounts for about $70-95 \%$ of the operating cost [22].

One of the potent and efficient substrates for production of biodiesel is vegetable oil since it is renewable in nature, readily available, and environment friendly. Both edible and non-edible oils have been vastly employed for this purpose. Alcohol esters of vegetable oils possess characteristics that are very close to that of diesel fuel [27]. Rapeseed and sunflower oil in Europe, soybean oil in USA, and palm oil in tropical countries have been used. Nonedible oils appropriate for application of biodiesel include Pongamia glabra, Attalea speciosa, Madhuca longifolia, Jatropha curcus, Nicotiana tabacum, Hevea brasiliensis, and Ricinus communis to name a few [4, 66]. In 2009, Li et al. [54] reported the use of Eruca sativa Gars oil for biodiesel production, yielding $98 \%$ conversion. Since edible oil is expensive, search for cheaper oil substrates has been a major focus in biodiesel research. Takahashi collected waste cooking oils from various sources such as cafeterias, restaurants, and households in the city of Kyoto and used it to produce biodiesel as an energy source [4]. Biodiesel production using high temperature pretreated kitchen garbage was reported by Su et al. [86]. Pizarro and Park [72] produced biodiesel using waste (bleaching earth) generated during the crude vegetable oil refining process, yielding $55 \%$ biodiesel.

Biodiesel production is also achieved by transesterification of vegetable oils with simple alcohols either using a catalyst or without it. Reaction temperature, alcohol to oil ratio, mixing speed, and purity of reactants are the other parameters which influence biodiesel production [7]. Optimization of these parameters has been widely researched to improve the biodiesel yield. Conventionally, acidic and alkaline catalysts have been widely employed for transesterification. Keera et al. [42] and Usta et al. [93] reported the best yield of biodiesel using sodium hydroxide as an alkaline catalyst for soybean oil and cottonseed oil transformation and both acid $\left(\mathrm{H}_{2} \mathrm{SO}_{4}\right)$ and base $(\mathrm{NaOH})$ catalysts for biodiesel production using soap stock. Of late, solid catalysts and enzymes are being used for biodiesel production. The French Institute of petroleum developed a large-scale industrial biodiesel production process (Esterfip-H) using solid catalysts of mixed oxide of zinc and aluminum [66]. In a similar study, Shu et al. [83] reported $80.5 \%$ conversion of triglyceride using a carbon-based solid acid catalyst for transesterification of cottonseed oil supplemented with oleic acid (50\% w/w). Enzyme-based biodiesel synthesis involves the use of lipase which provides an added advantage of simple separation and purification of the reaction products. The enzymatic production of fatty acid methyl ester was established at Lvming Co. Ltd. in China where immobilized lipase was used for transesterification of waste cooking oil [4]. Up to $30 \%$ yield was reported by Zeng et al. [103] using whole cell Rhizopus oryzae IFO 4697 as biocatalysts. Many other unique techniques have been employed for biodiesel production, aiming at energy and material conservation. In one such attempt, a $99 \%$ yield was attained within 50 min by adopting ultrasonic irradiation $(20 \mathrm{kHz})$ for transesterification of Canola 
Fig. 1 Flow diagram for bioethanol/biobutanol production from vegetable wastes

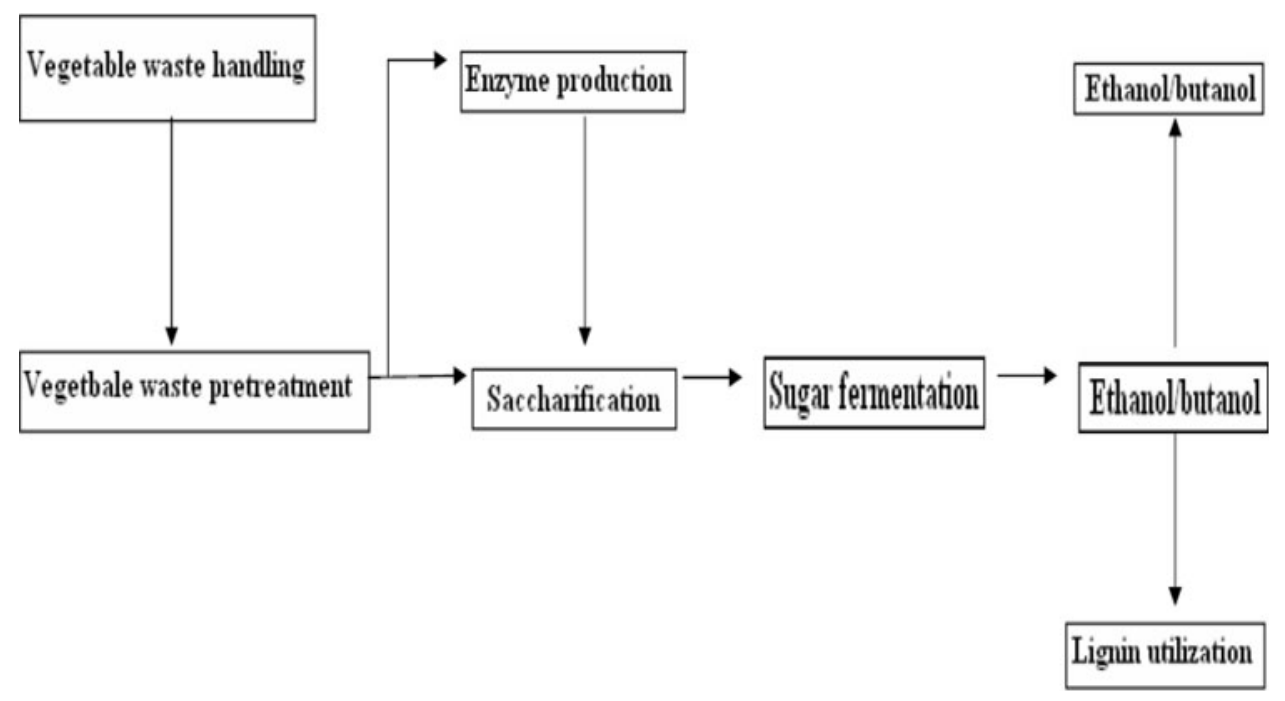

oil [91]. Employing supercritical fluid extraction, Lee et al. [51] obtained a high yield of biodiesel (approx. $100 \%$ ) from waste Canola oil in $45 \mathrm{~min}$ of incubation time. Research aiming at improving the process of transesterification is under progress with a focus not only on the yield, but also on environmental safety and resource conservation in the form of feedstock availability, recovery, and economy.

\section{Bioethanol and Biobutanol}

The wastes from fruit and vegetable processing industries being rich in polysaccharides (cellulose, hemi-cellulose and lignin) can be subjected to solid state fermentation for the production of ethanol and butanol, which has several uses $[37,50]$ such as a solvent in many industries and also as a liquid fuel supplement.

The basic processes for converting sugar and starch crops are well known and used commercially. While these types of plants generally have a greater value as a food source rather than as a fuel source, there are some exceptions to this [32]. Vegetable waste can be a potential substrate for bioethanol and biobutanol production due to its availability in abundance, high cellulose and starch content, and non-competitiveness with our food chain [88]. Vegetable waste to biofuel production consists of biomass pretreatment, saccharification, and fermentation. The general process for bioethanol/biobutanol production from vegetable wastes has been given in Fig. 1.

Ethanol has been a key industrial chemical for many years. Fuel ethanol, in particular, is considered more environment friendly than fossil fuels. It has been seen as a replacement for gasoline. The potential microorganisms for ethanol fermentation include Saccharomyces cerevisiae, Zymomonas mobilis, C(full name)thermocellum, and recombinant Escherichia coli [15, 44, 79]. S. cerevisiae [55] is widely used for industrial ethanol production because of its ability to produce high concentrations of ethanol from hexoses and because of its high tolerance to ethanol and other inhibitory compounds (Table 3). There are a few reports on scaling up studies of bioethanol production from vegetable wastes. Tang et al. [88] reported bioethanol production at 2001 scale using kitchen wastes. Patle and Lal [70] reported bioethanol production from various agricultural biomasses at 51 scale. However, the following crucial issues need to be addressed for commercial production of bioethanol: (i) the development of pretreatment method which can significantly remove lignin without altering cellulose; (ii) the development of an efficient saccharification process; (iii) the development of industrially viable strains for efficient fermentation of mixed-sugar hydrolyzates containing both hexoses and pentoses sugars that would also be resistant to the presence of inhibitory compounds such as those produced by delignification.

For the development of bioconversion processes, the major challenges in ethanol production are as follows: (i) reduction of lignin content of plant biomass genetically [14, 16]; (ii) development of innovative technologies for efficient pretreatment of lignocellulosic biomass [5, 37]; (iii) standardization of a process for simultaneous utilization of pentose and hexose sugars from single reactor vessel; (iv) genetic modification to develop high ethanol-tolerant strains. Research activities are underway for development of simultaneous saccharification and fermentation processes for bioethanol production. This has several advantages as both saccharification and fermentation are carried out in a single vessel and inhibition of the microorganisms by the end product is thus avoided. Table 3 summarizes bioethanol production from different types of vegetable wastes.

Butanol is another important industrial chemical feedstock, but it also has a potential for use as biofuel. The production of biobutanol by fermentation for use as a 
Table 3 Bioethanol production from several types of food wastes

\begin{tabular}{|c|c|c|c|c|}
\hline Substrates & Micro-organisms & Incubation time $(\mathrm{h})$ & Ethanol yield $\left(\mathrm{g} \mathrm{l}^{-1}\right)$ & References \\
\hline Potato peel & S. cerevisiae & $24-48$ & $7-20$ & {$[2,101,102]$} \\
\hline Apple pomace, waste apples & S. cerevisiae & $72-96$ & $8.44-77.32$ & {$[10,87]$} \\
\hline Banana peel, banana waste & S. cerevisiae & $96-120$ & $16.96-56.02$ & {$[20]$} \\
\hline Beet waste, beet pomace & S. cerevisiae & 96 & $14.99-116$ & {$[20,35]$} \\
\hline Kitchen garbage, kitchen waste & S. cerevisiae & $24-67.6$ & $30-33.05$ & {$[88,100]$} \\
\hline Pineapple waste & S. cerevisiae & 72 & $2.54-68.64$ & {$[35]$} \\
\hline Soybean litter, soybean molasses & S. cerevisiae & $24-40$ & $1.16-63.5$ & [84] \\
\hline
\end{tabular}

biofuel is gaining interest as it offers several advantages in comparison to bioethanol [105]. The main producers of biobutanol are Clostridia-obligate anaerobic, rod-shaped, and spore-forming gram positive bacteria. However, the number of Clostridium spp. capable of producing significant amounts of butanol during fermentation is very low. Fermentation of saccharified lignocellulosics by Clostridia produces acetone:butanol:ethanol in the ratio of 3:6:1 [57]. Clostridia have been categorized on the basis of their type and the ratio of the solvent produced [43]. The most common species for butanol production is Clostridium acetobutylicum [57]. Clostridium beijerinckii is also producing butanol nearly in the same ratio as $C$. acetobutylicum. It replaces acetone by isopropanol, while Clostridium aurantibutyricum produces both along with butanol. Grobben et al. [31] reported the maximum biobutanol production $\left(22 \mathrm{~g} \mathrm{l}^{-1}\right)$ from potato processing waste after $40 \mathrm{~h}$ of fermentation. Voget et al. [99] reported $2.2 \%$ biobutanol production from apple pomace. Patáková et al. [69] reported 15.23 and $13.70 \mathrm{~g} \mathrm{l}^{-1}$ biobutanol production from maize and sugar beet molasses, respectively.

Bioethanol and biobutanol have been used as promising alternatives to petroleum-based transportation fuels. Vegetables wastes represent one of the important biomass sources that have a potential to be converted into ethanol and butanol. Examples of these wastes for biofuel production include potato peel wastes, apple pomace, orange peel, carrot residues, etc. Conversion of these wastes into biofuel not only produces value-added products, but also reduces the disposal costs of these wastes.

\section{Biohydrogen}

Biohydrogen is a potential biofuel because of its easy availability, environment friendly nature, and high energy content. Application of hydrogen energy is associated with high conversion efficiency obtained from fuel cells [24, 28]. It is one of the cleanest fuels because of zero $\mathrm{CO}_{2}$ emission and a propensity for replacing depleted oil reserves [29, 30]. Among all the methods of hydrogen production, fermentative hydrogen production via light- dependent and dark fermentative processes has several advantages [39, 82]. Photolysis and photo-fermentation are included under light-dependent processes which are aerobic, whereas dark fermentation takes place in anaerobic conditions [82], which increases the rate of hydrogen generation and thus reduces the cost of production.

Substrates used for biohydrogen production using suitable bio-process technologies should be carbohydrate-rich nitrogen-deficient solids. Among all wastes, vegetable wastes are considered to be one of the probable natural substrates having the potentiality of generating energy due to their high organic content and easy biodegradability. Cultures-pure, mixed, or co-culture-are other conditions for improving the productivity. Potential microorganisms contributing significantly in biohydrogen production processes are green algae, cyanobacteria, purple non-sulfur bacteria, which are photosynthetic and fermentative, etc. $[71,82]$. Other strategies for improving $\mathrm{H}_{2}$ yields are pretreatment, gas sparging, reduction of $\mathrm{H}_{2}$ and $\mathrm{CO}_{2}$ levels in the liquid phase, nutrient availability, $\mathrm{pH}$, and temperature [43, 47]. Researchers the world over have used such approaches for increasing biohydrogen generation. Mohanakrishna et al. [60] used vegetable wastes for hydrogen production and showed an increase of up to $55 \%$ with sewage supplementation. Similarly, Marone et al. [58] used a different approach of bioaugmentation of microbial communities for increasing the hydrogen production using market vegetable waste. Three different $\mathrm{H}_{2}$ producing strains when put together maximize the $\mathrm{H}_{2}$ production as compared to self-fermentation of each individual strain. A different strategy was adopted by Tenca et al. [90] for achieving maximum hydrogen production without controlling the $\mathrm{pH}$ externally. They co-fermented vegetable feedstock with alkali-rich material, i.e., swine manure, to avoid external adjustments of $\mathrm{pH}$. Wastes generated from potato processing industries were utilized by Dong et al. [23] and Logan et al. [56] for increased production of biohydrogen from 15 to $55 \%$. Carrot and cabbage were also selected for estimating the potential for hydrogen production [65]. Other wastes used for hydrogen production were lettuce and sugar beet, and in all these cases the 
researchers concentrated mostly on the rate of hydrogen production and the yield of the process.

The other issue which further needs to be dealt with for biohydrogen production is bioreactor designing. Both light phase and dark fermentation bioreactor models were used for maximizing the biohydrogen yield. Photo bioreactors require a large surface to volume ratio and their light dependency increases operational cost. Thus, dark fermentation is stipulated, which can be done in any of the different types of bioreactors such as CSTR, anaerobic sequencing batch reactor, membrane bioreactor, fixed-bed bioreactor, fluidized-bed bioreactor, expanded granular sludge bed reactor, and UASB bioreactor. Among these, the anaerobic CSTR is one such reactor which has been used for biohydrogen generation using vegetable wastes as reported by Jaitalee et al. [36] and Shi et al. [81]. Philippis et al. [71] tried scaling up from 2.5 to 111 bioreactor for monitoring the biohydrogen production rate with encouraging results toward industrialization of biohydrogen production.

Thus, production of biohydrogen by utilizing vegetable wastes is a clean method for converting waste to energy and addressing the issues of sustainability, environmental emissions, and energy security.

\section{Conclusion}

Climate change mitigation, energy security, rising oil prices, and economic objectives are stimulating a strong interest in the development of bioenergy. Progress in potential, environment friendly biofuel supply chains from vegetable wastes is taking shape. Among several conversion processes and product developments, biomethane and bioethanol production from various food and vegetable wastes appears to be economically feasible on a large scale.

Developments in bioenergy generation would, in the future, influence the activities of the food and vegetable sectors as the pressure on waste management and bioproduct development increases. As with any biofuel production, the sustainable re-use of food and vegetable waste resources would not be without difficulties, but it would make available the opportunity for biotechnological developments. The economic environment would need to promote the type of conditions in which the growing food and vegetable industries can succeed.

While the developing countries are still struggling with socio-economic issues, mitigation of the massive energy shortage demands the meeting of the crisis through development of biotechnological solutions in the food and vegetable sectors by selecting suitable processes for maximizing energy generation. Committed leadership, suitable planning, technical and managerial support, public awareness, and growth in financing infrastructure are the probable requirements for making large-scale bioenergy generation feasible. Finally, the vision of resource and energy management along with conservation of the environment could be attained by integrating waste and energy.

\section{References}

1. Afifi MM (2011) Enhancement of lactic acid production by utilizing liquid potato wastes. Int J Biol Chem 5:91-102

2. Arapoglou D, Varzakas T, Vlyssides A, Israilides C (2010) Ethanol production from potato peel waste (PPW). Waste Manag 30:1898-1902

3. Assi JA, King AJ (2008) Manganese amendment and Pleurotus ostreatus treatment to convert tomato pomace for inclusion in poultry feed. Poult Sci 87:1889-1896

4. Atadashi IM, Aroura MK, Abdul-Aziz AR, Sulaiman NMN (2012) Production of biodiesel using high free fatty acid feedstocks. Renew Sustain Energy Rev 16:3275-3285

5. Balat M, Balat H, Öz C (2008) Progress in bioethanol processing. Prog Energy Combust Sci 34:551-573

6. Bao B, Chang KC (1994) Carrot pulp chemical composition, color, and water holding capacity as affected by blanching. J Food Sci 59:1159-1161

7. Barnwal BK, Sharma MP (2005) Prospects of biodiesel production from vegetable oils in India. Renew Sustain Energy Rev 9:363-378

8. Barth C, Powers T (2008) Agricultural waste characteristics. Agricultural waste management field handbook, United States Department of Agriculture, South Carolina, pp 1-32

9. Benítez V, Mollá E, Martín-Cabrejas MA, Aguilera Y, LópezAndréu FJ, Cools K, Terry LA, Esteban RM (2011) Characterization of industrial onion wastes (Allium cepa L.): dietary fibre and bioactive compounds. Plant Foods Hum Nutr 66:48-57

10. Bouallagui H, Cheikh RB, Marouani L, Hamdi M (2003) Mesophilic biogas production from fruit and vegetable waste in tubular digester. Bioresour Technol 86:85-90

11. Bouallagui H, Torrijos M, Godon JJ, Moletta R, Ben Cheikh R, Touhami Y, Delgenes JP, Hamdia M (2004) Two-phases anaerobic digestion of fruit and vegetable wastes: bioreactors performance. Biochem Eng 21:193-197

12. Bouallagui H, Touhami Y, Ben Cheikh R, Hamdi M (2005) Bioreactor performance in anaerobic digestion of fruit and vegetable wastes. Process Biochem 40:989-995

13. Bouallagui H, Rachdi B, Gannoun H, Hamdi M (2009) Mesophilic and thermophilic anaerobic co-digestion of abattoir wastewater and fruit and vegetable waste in anaerobic sequencing batch reactors. Biodegradation 20:401-409

14. Chantanta DK, Attri C, Gopal K, Devi M, Gupta G, Bhalla TC (2008) Bioethanol production from apple pomace left after juice extraction. Internet J Microbiol 5:2

15. Chen Y (2011) Development and application of co-culture for ethanol production by co-fermentation of glucose and xylose: a systematic review. J Ind Microbiol Biotechnol 35:581-597

16. Chen F, Dixon RA (2007) Lignin modification improves fermentable sugar yields for biofuel production. Nat Biotechnol 25:759-761

17. CPCB (2007) Bio-methanation potential of solid wastes from agro-based industries. Ministry of Environment and Forests Government of India, New Delhi

18. CPCB (2007) Sponge iron industry., Comprehensive industry document seriesCentral Pollution Control Board, Ministry of Environment and Forests, Government of India, India 
19. Das H, Singh SK (2004) Useful byproducts from cellulosic wastes of agriculture and food industry - a critical appraisal. Crit Rev Food Sci Nutr 44:77-89

20. Dhabekar A, Chandak A (2010) Utilization of banana peels and beet waste for alcohol production. Asiatic J Biotech Res 1:8-13

21. Dinsdale RM, Premier GC, Hawkes FR, Hawkes DL (2000) Two-stage anaerobic co-digestion of waste activated sludge and fruit/vegetable waste using inclined tubular digesters. Bioresour Technol 72:159-168

22. Diyauddeen BH, Abdul Aziz AR, Daud WMAW, Chakrabarti MH (2012) Performance evaluation of biodiesel from used domestic waste oils: a review. Process Saf Environ Prot. doi: 10.1016/j.psep.2012.02.005

23. Dong L, Zhenhong Y, Yongming S, Xiaoying K, Yua Z (2009) Hydrogen production characteristics of the organic fraction of municipal solid wastes by anaerobic mixed culture fermentation. Int J Hydrogen Energy 34:812-820

24. Edwards PP, Kuznetsov VL, David WI (2007) Hydrogen energy. Philos Transact A Math Phys Eng Sci 365:1043-1056

25. Fallon E, Tremblay N, Desjardins Y (2006) Relationships among growing degree-days, tenderness, other harvest attributes and market value of processing pea (Pisum sativum L.) cultivars grown in Quebec. Can J Plant Sci 86:525-537

26. FAO (2011) Global food losses and food waste: extent, causes and prevention. FAO, Rome

27. Ghassan T, Al-Widyan MI, Al-Shyoukh AO (2003) Combustion performance and emissions of ethyl ester of a waste vegetable oil in a water-cooled furnace. Appl Therm Eng 23:285-293

28. Gomes-Antunes JM, Mikalsen R, Roskilly AP (2008) An investigation of hydrogen-fuelled HCCI engine performance and operation. Int J Hydrogen Energy 33:5823-5828

29. Gomez MJC, Cara J, Morán A, García AI (2006) Anaerobic codigestion of primary sludge and the fruit and vegetable fraction of the municipal solid wastes. Conditions for mixing and evaluation of the organic loading rate. Renew Energy 31:2017-2024

30. Gomez X, Fernandez C, Fierro J, Sanchez ME, Escapa A, Moran A (2011) Hydrogen production: two stage processes for waste degradation. Bioresour Technol 102:8621-8627

31. Grobben NG, Eggink G, Cuperus FP, Huizing HJ (1993) Production of acetone, butanol and ethanol (ABE) from potato wastes: fermentation with integrated membrane extraction. Appl Microbiol Biotechnol 39:494-498

32. Hamelinck CN, Hooijdonk G, Faaij APC (2005) Ethanol from lignocellulosic biomass: techno-economic performance in short, middle- and long-term. Biomass Bioenergy 28:384-410

33. Hampannavar US, Shivayogimath CB (2010) Anaerobic treatment of sugar industry wastewater by upflow anaerobic sludge blanket reactor at ambient temperature. Int $\mathrm{J}$ Environ Sci 1:631-639

34. Hills DJ, Nakano L (1984) Effects of particle size on anaerobic digestion of tomato solid waste. Agric Wastes 10:285-295

35. Hossain ABMS, Fazliny AR (2010) Creation of alternative energy by bio-ethanol production from pineapple waste and the usage of its properties for engine. Afr $\mathrm{J}$ Microbiol Res 4: 813-819

36. Jaitalee L, Dararat S, Chavalparit O (2010) Bio-hydrogen production potential from market waste. Environ Asia 3:115-122

37. Jørgensen H, Kristensen JB, Felby C (2007) Enzymatic conversion of lignocellulose into fermentable sugars: challenges and opportunities. Biofuel Bioprod Biorefin 1:119-134

38. Joshi VK, Pandey A, Sandhu DK (1999) Fermentation technology for food industry waste utilization. In: Joshi VK, Ashok $\mathrm{P}$ (eds) Biotechnology: food fermentation, microbiology, biochemistry and technology, vol II. Educational Publishers and Distributors, New Delhi, pp 1291-1348
39. Kapdan IK, Kargi F (2006) Bio-hydrogen production from waste materials. Enzyme Microb Technol 38:569-582

40. Karmakar A, Karmakar S, Mukherjee S (2010) Properties of various plants and animals feedstocks for biodiesel production. Bioresour Technol 101:7201-7210

41. Kavitha P, Ramana JV, Prasad RJ, Reddy PVVS, Reddy PS (2005) Nutritive value of dried tomato (Lycopersicon esculentum) pomace in cockerels. Animal Nutr Feed Technol 5: 107-111

42. Keera ST, El Sabagh SM, Taman AR (2011) Transesterification of vegetable oil to biodiesel fuel using alkaline catalyst. Fuel 90:42-47

43. Kharkwal G (2009) Qualitative analysis of tree species in evergreen forests of Kumaun Himalaya, Uttarakhand, India. Afr J Plant Sci 3:49-52

44. Kim Y, Ingram LO, Shanmugam KT (2007) Construction of an Escherichia coli K-12 mutant for homoethanologenic fermentation of glucose or xylose without foreign genes. Appl Environ Microbiol 73:1766-1771

45. Klingspohn U, Bader J, Kruse B, Kishore PV, Schiiger K, Kracke-Helm HA, Likidis Z (1993) Utilization of potato pulp from potato starch processing. Process Biochem 28:91-98

46. Knol W, Van der most MM, Dewart J (1978) Biogas production by anaerobic digestion of fruit and vegetable wastes. A preliminary study. J Sci Food Agric 29:822-830

47. Kraemer JT, Bagley DM (2007) Improving the yield from fermentative hydrogen production. Biotechnol Lett 29:685-695

48. Kramer A, Kwee WH (1977) Utilization of tomato processing wastes. J Food Sci 42:212-215

49. Lane AG (1984) Laboratory scale anaerobic digestion of fruit and vegetable solid waste. Biomass 5:245-259

50. Laufenberg G, Kunz B, Nystroem M (2003) Transformation of vegetable waste into value added products: (A) the upgrading concept; (B) practical implementations. Bioresour Technol 87:167-198

51. Lee S, Posarac D, Ellis N (2012) An experimental investigation of biodiesel synthesis from waste canola oil using supercritical methanol. Fuel 91:229-237

52. Lehto M, Sorvala S, Kemppainen R, Salo T, Puumala M (2005) Wastes and wastewaters from vegetable peeling processes. Information and Technology for Sustainable Fruit and Vegetable Production, Montpellier

53. Lenihan P, Orozco A, O'Neill E, Ahmad MNM, Rooney DW, Mangwandi C, Walker GM (2011) Kinetic modelling of dilute acid hydrolysis of lignocellulosic biomass. In: Bernardes MAS (ed) Biofuel production-recent developments and prospects. InTech, Croatia, pp 293-308

54. Li S, Wang Y, Dong S, Chen Y, Cao F, Chai F, Wang X (2009) Biodiesel production from Eruca sativa Gars vegetable oil and motor, emissions properties. Renew Energy 34:1871-1876

55. Lin Y, Tanaka S (2006) Ethanol fermentation from biomass resources: current state and prospects. Appl Microbiol Biotechnol 69:627-642

56. Logan B, Eunoh S, Kim I, Ginkel SV (2002) Biological hydrogen production measured in batch anaerobic respirometers. Environ Sci Technol 36:2530-2535

57. Lütke-Eversloh T, Bahl H (2011) Metabolic engineering of Clostridium acetobutylicum: recent advances to improve butanol production. Curr Opin Biotechnol 22:634-647

58. Marone A, Massini G, Patriarca C, Signorini A, Varrone C, Izzo G (2012) Hydrogen production from vegetable waste by bioaugmentation of indigenous fermentative communities. Int $\mathbf{J}$ Hydrogen Energy 37:5612-5622

59. Mayer F (1998) Potato pulp: properties, physical modification and applications. Polym Degrad Stab 59:231-235 
60. Mohanakrishna G, Goud RK, Mohan SV, Sarma PN (2010) Enhancing biohydrogen production through sewage supplementation of composite vegetable based market waste. Int $\mathbf{J}$ Hydrogen Energy 35:533-541

61. Mojtahedi M, Mesgaran MD (2009) Variability in the chemical composition and in situ ruminal degradability of sugar beet pulp produced in North-East Iran. Res J Biol Sci 4:1262-1266

62. Molinuevo-Salces B, González-Fernández C, Gómez X, Cruz García-González M, Morán A (2012) Vegetable processing wastes addition to improve swine manure anaerobic digestion: evaluation in terms of methane yield and SEM characterization. Appl Energy 91:36-42

63. Murphy JD, Power N (2009) Technical and economic analysis of biogas production in Ireland utilizing three different crop rotations. Appl Energy 86:25-36

64. Nawirska A, Kwaniewska M (2005) Dietary fibre fractions from fruit and vegetable processing waste. Food Chem 91:221-225

65. Okamoto M, Miyahara T, Mizuno O, Noike T (2000) Biological hydrogen potential of materials characteristic of the organic fraction of municipal solid wastes. Water Sci Technol 41(3): $25-32$

66. Olivera SS, Ana VV, Vlada BV (2011) The production of biodiesel from vegetable oils by ethanolysis: current state and perspectives. Fuel 90:3141-3155

67. Parawira W, Murto M, Zvauya R, Mattiasson B (2004) Anaerobic batch digestion of solid potato waste alone and in combination with sugar beet leaves. Renew Energy 29:1811-1823

68. Parawira W, Murto M, Zvauya R, Mattiasson B (2006) Comparative performance of a UASB reactor and an anaerobic packed-bed reactor when treating potato waste leachate. Renew Energy 31:893-903

69. Patáková P, Lipovský J, Čížková H, Fořtová J, Rychtera M, Melzoch K (2009) Exploitation of food feedstock and waste for production of biobutanol. Czech J Food Sci 27:276-283

70. Patle S, Lal B (2007) Ethanol production from hydrolysed agricultural wastes using mixed culture of Zymomonas mobilis and Candida tropicalis. Biotechnol Lett 29:1839-1843

71. Philippis RD, Bianchi L, Colica G, Bianchini C, Peruzzini M, Vizza F (2007) From vegetable residues to hydrogen and electric power: feasibility of a two step process operating with purple non sulfur bacteria. J Biotechnol 131:S122-S123

72. Pizarro AVL, Park EY (2003) Lipase-catalyzed production of biodiesel fuel from vegetable oils contained in waste activated bleaching earth. Process Biochem 38:1077-1082

73. Rajeshwari KV, Lata K, Pant DC, Kishore VVN (2001) A novel process using enhanced acidification and a UASB reactor for biomethanation of vegetable market waste. Waste Manag res 19:4292-4300

74. Raynal J, Delgenks JP, Moletta R (1998) Two phase anaerobic digestion of solid wastes by a multiple liquefaction reactors process. Bioresour Technol 65:97-103

75. Rizal Y, Mahata ME, Andriani M, Wu G (2010) Utilization juice wastes as corn replacement in the broiler diet. WASET 68:1449-1452

76. Saev M, Koumanova B, Simeonov I (2009) Anaerobic codigestion of wasted tomatoes and cattle dung for biogas production. J Univ Chem Tech Metallurgy 44:55-60

77. Sagagi BS, Garba B, Usman NS (2009) Studies on biogas production from fruits and vegetables waste. Bayero J Pure Appl Sci 2:115-118

78. Sarada R, Joseph R (1994) Studies on factors influencing methane production from tomato-processing waste. Bioresour Technol 47:55-57

79. Senthilkumar V, Gunasekaran P (2005) Bioethanol production from cellulosic substrates: engineered bacterial and process integration challenges. J Sci Ind Res 64:845-853
80. Sharma KD, Karki S, Thakur NS, Attri S (2012) Chemical composition, functional properties and processing of carrot-a review. J Food Sci Technol 49:22-32

81. Shi Y, Gai G, Zhao X, Hu Y (2009) Influence and simulation model of operational parameters on hydrogen bio-production through anaerobic microorganism fermentation using two kinds of wastes. In: Proceedings of the world congress on "engineering and computer science" held during Oct 20-22 at San Francisco, USA

82. Show KY, Lee DJ, Chang JS (2011) Bioreactor and process design for biohydrogen production. Bioresour Technol 102: 8524-8533

83. Shu Q, Gao J, Nawaz Z, Liao Y, Wang D, Wang J (2010) Synthesis of biodiesel from waste vegetable oil with large amounts of free fatty acids using a carbon-based solid acid catalyst. Appl Energy 87:2589-2596

84. Siqueira PF, Karp SG, Carvalho JC, Sturma W, Rodríguez-León JA, Jean-Luc T, Singhania RR, Pandey A, Soccol CR (2008) Production of bio-ethanol from soybean molasses by Saccharomyces cerevisiae at laboratory, pilot and industrial scales. Bioresour Technol 99:8156-8163

85. Stewart DJ, Bogue MJ, Badger DM (1984) Biogas production from crops and organic wastes. NZ J Sci 27:285-294

86. Su W, Ma H, Gao M, Zhang W, Wang Q (2010) Research on biodiesel and ethanol production from food waste. The project was supported by the 11th five years key programs for science and technology support of China

87. Tahir A, Sarwar S (2012) Effect of cultural condition on production of ethanol from rotten apple waste by Saccharomyces cerevisiae straining. Can J App Sci 2:187-195

88. Tang YQ, Koike Y, Liu K, An MZ, Morimura S, Wu XL, Kida K (2008) Ethanol production from kitchen waste using the flocculating yeast Saccharomyces cerevisiae strain KF-7. Biomass Bioenergy 32:1037-1045

89. Tembhurkar AR, Mhaisalkar VA (2006) Study of hydrodynamic behavior of a laboratory scale upflow anaerobic fixed film fixed bed reactor. J Environ Sci Eng 48:75-80

90. Tenca A, Schievano A, Perazzolo F, Adani F, Oberti R (2011) Biohydrogen from thermophilic co-fermentation of swine manure with fruit and vegetable waste: maximizing stable production without $\mathrm{pH}$ control. Bioresour Technol 102:85828588

91. Thanh LT, Okitsu K, Sadanaga Y, Takenaka N, Maeda Y, Bandow H (2010) Ultrasound-assisted production of biodiesel fuel from vegetable oils in a small circulation process. Bioresour Technol 101:639-645

92. Trujillo D, Perez JF, Cebre FJ (1993) Energy recovery from wastes: anaerobic digestion of tomato plant mixed with rabbit wastes. Bioresour Technol 45:81-83

93. Usta N, Ozturk EO, Can O, Conkur ES, Nas S, Con AH (2005) Combustion of biodiesel fuel produced from hazelnut soapstock/ waste sunflower oil mixture in a diesel engine. Energy Convers Manag 46:741-755

94. Uzodinma EO, Ofoefule AU, Enwere NJ (2011) Optimization of biogas fuel production from maize (Zea mays) bract waste: comparative study of biogas production from blending maize bract with biogenic wastes. Am Food Nutr 1:1-6

95. Velmurugan B, Ramanujam RA (2011) Anaerobic digestion of vegetable wastes for biogas production in a fed-batch reactor. Int J Emerg Sci 1:478-486

96. Verma N, Bansal NC, Kumar V (2011) Pea peel waste: a lignocellulosic waste and its utility in cellulose production by Trichoderma reesei under solid state cultivation. Bioresources 6:1505-1519

97. Verrier D, Ray F, Albagnac G (1987) Two phase methanation of solid vegetable wastes. Biol Wastes 22:163-177 
98. Viswanath P (1992) Anaerobic digestion of fruit and vegetable processing wastes for biogas production. Bioresour Technol 40:43-48

99. Voget CE, Mignone CF, Ertola RJ (1985) Butanol production from apple pomace. Biotechnol Lett 7:43-46

100. Wang Q, Ma H, Xu W, Gong L, Zhang W, Zou D (2008) Ethanol production from kitchen garbage using response surface methodology. Biochem Eng J 39:604-610

101. Wantanee A, Sureelak R (2004) Laboratory scale experiments for biogas production from cassava tubers. In: The joint international conference on "sustainable energy and environment (SEE)" held during Dec 1-3 at Hua Hin, Thailand

102. Yamada S, Shinomiya N, Ohba K, Sekikawa M, Oda Y (2009) Enzymatic hydrolysis and ethanol fermentation of by-products from potato processing plants. Food Sci Technol Res 15: 653-658

103. Zeng J, Du W, Liu X, Liu D (2006) Study on the effect of cultivation parameters and pretreatment on Rhizopus oryzae cell-catalyzed transesterification of vegetable oils for biodiesel production. J Mol Catal B Enzyme 43:15-18

104. Zhang B, Zhang LL, Zhang SC, Shi HZ, Cai WM (2005) The influence of $\mathrm{pH}$ on hydrolysis and acidogenesis of kitchen waste in two phase anaerobic digestion. Environ Technol 20: 320-330

105. Zverlov VV, Berezina O, Velikodvorskaya GA, Schwarz WH (2006) Bacterial acetone and butanol production by industrial fermentation in the Soviet Union: use of hydrolyzed agricultural waste for biorefinery. Appl Microbiol Biotechnol 71:587-597 